\title{
reviews
}

Controversy: Politics of Technical Decisions. Edited by Dorothy Nelkin. Pp. 256. (Sage Publications: Beverly Hills and London, 1979.) Hardback \$16, £10; paperback $\$ 7.95, £ 5$.

SCIENCE-AND-SOCIETY, hyphenated like this, is now a well established subject for study, with departments, professors, journals, conferences, research grants: all the apparatus of an academic discipline except a codified content. This is not a pejorative assertion. A codified content takes time to evolve; premature generalisations might become obstacles to evolution; the most helpful contributions to make at this stage are in the 'natural history' of the subject: descriptions of what actually happens (the echo of Ranke's recipe for writing history "wie es eigentlich gewesen") and cautious comparisons of what seem to be similar episodes.

This is what Dorothy Nelkin has been doing for some time. She has published case-studies of controversies about the siting of a nuclear power station, about the extension of the Boston airport, about housing politics, about military research at MIT; all controversies: for the first lesson the novice has to learn in this subject is that sweetness-and-light is not only impracticable, it is undesirable. Controversy is essential to the resolution of the problems that arise from the applications of technology to social ends. It's a consequence of political freedom. So attention has to be given, not to the elimination of controversy but to its management. Who has the right to take part? How can those who take part have access to information? What is the appropriate forum for the controversy: a court of law, a ministerial public enquiry, a panel of experts, a clash of pressure groups? Experiments which might provide answers to these questions are going on all the time. The Royal Commission on Electric Power Planning in Ontario has published some notable material; so has the Electric Power Research Institute in California; so, in Britain, has the Advisory Committee on Trunk Road Assessment. But the most useful material for the student is a collection of documented case-studies, as little coloured by prejudice as is possible in a subject where exaggeration, sensationalism, and distortion of the facts are the very raw material in the process.

This is what Dorothy Nelkin has achieved in her editorship of this useful collection of twelve case-studies in the politics of technical decisions. The studies are intended to "provide students with a sense of the kind of reasoning that motivates public agencies, government officials, scientists, and protest groups". She distinguishes four kinds of controversy and the contributors to the volume give three examples of each kind. They are: efficiency versus equity, as in the siting of an airport; benefits versus risks, as in the controversy over nuclear wastes; regulation versus freedom of choice, as in the prescription of certain drugs not because they are dangerous but because they appear to be useless; and science (the rational approach to nature) versus traditional values (opposition to the pursuit of knowledge irrespective of where it might lead.) Each case-study is well supported by references to primary sources.

I would like someone to write a monograph on controversies about airports. Heathrow is a shameful example of the incompetence of the British in the planning of air transport and the futility of the present state-of-the-art of technology assessment. But we have no monopoly of incompetence. In the 1950 s there was a vast investment in Gander airport in Newfoundland, "just before the introduction of jet aircraft made nonstop trans-Atlantic flights possible'. Then, as a case-study of the Toronto airport goes on to explain, came the proposal to site a second airport in Toronto. One motive was rivalry with Montreal; if Toronto didn't expand, Montreal would become the "gateway to Canada". Another motive was to pacify people living near the present airport. Opposition to a new airport developed rapidly, just as it is now doing in Britain to oppose any site for a third London airport. It coalesced under a good emotive label: POP - People or Planes. Among the supporters of the opposition was one aircraft manufacturer, who saw a better market for short take-off craft if there were to be only one airport in Toronto. One interesting and significant point which the essay makes is that the real issues were political but they were often camouflaged as scientific or technical.

The most interesting essay in the book, because it draws upon almost inaccessible sources, is one on environmental conflict in the USSR. With a wealth of references, almost all Russian, Thane Gustafson describes the awakening of an environmental conscience in the Soviet Union. He effectively dispels any notion that it came from the grassroots. But he shows that the genuine concern about the condition of Lake Baikal was not solely for commercial expediency: "Through literature and folklore, every Russian from childhood knows its beauty". And this was a powerful factor in the campaign to clean the lake. Concern for water management and opposition to the siting of dams arose because it was causing a serious alienation of valuable agricultural land. But the new environmental programme owes its impetus to the influence of scientists, aware of the concern for conservation in Europe and America, who have made themselves audible in the councils of the Kremlin.

All the case-studies are interesting and a few comments on them will illustrate how well they have been chosen. The familiar ban on the use of diethylstilbestrol (DES) is an example of the need to balance the benefits of more meat against the potential disbenefits of cancer: one a certainty, the other an unproven possibility. It is noteworthy that the Food and Drug Administration avoided justifying the ban on grounds of the notorious Delaney Clause because President Nixon proposed to Congress that this clause should be "diluted" to avoid some of the more crazy consequences of its application "to ban all foods because they contain a few molecules of naturally occurring carcinogens".

There is a historical chapter, showing that controversies about the uses of science are nothing new, which traces the opposition to smallpox immunisation in the eighteenth and nineteenth centuries. And there is an ominous account of an attempt - yes, as late as the $1970 \mathrm{~s}$ - to give equal treatment to the theories of evolution and of special creation in the teaching of biology in California. California buys about $10 \%$ of the nation's textbooks and it was seriously proposed that special creationists should have at least equal consideration in textbooks with the consideration given to orthodox biology. The National Academy and the American Association for the Advancement of Science had to throw their weight into the controversy. Perhaps we should not be surprised; astrologists can still make a good living in Britain and it is often said that more people make a living out of astrology than out of astronomy.

This book is a useful addition to a small, 
but growing, literature of case-studies of this kind. By far the best, though its scope is limited to planning enquiries, is Roy Gregory's The Price of Amenity (Macmillan, 1971). There is also, for British examples, the book edited by Peter Smith, The Politics of Physical Resources (Penguin, 1975), though some of the essays in this book are far from objective; and a book edited by R. Kimber and J.P. Richardson, Campaigning for the Environment (Routledge and Kegan Paul, 1974). The most comprehensive summary, though the case-studies are unfortunately

\section{Encyclopaedic approach to technology}

A History of Technology. Vols VI and VII: The Twentieth Century, c. 1900 to c. 1950. Edited by T.I. Williams. (Clarendon/Oxford University Press: Oxford, UK, 1979.) $£ 25$ and $£ 27$.

TWENTY-FIVE years ago the now classic first volume of $A$ History of Technology appeared from the Clarendon Press. This year, we welcome the sixth and seventh (and last) volumes in the series. With them we arrive, in history, where the series itself began, in the early 1950s. Together, these seven magnificent volumes form a monument of scholarship. Monuments normally inspire criticism or veneration; rarely use. This one is different.

From the early days of his collaboration with Charles Singer, E.J. Holmyard and A.R. Hall, Williams enjoyed the cooperation of a legion of eminent scholars whose unquestioned technical expertise made their contributions definitive. In editorial standards, range and clarity, the present volumes continue their predecessors' tradition of high scholarship. Nonetheless, 25 years is a long time in historiography, as in technology. Moreover, a new generation (and profession) of historians has emerged, with significantly altered perceptions of the social function of technology and technologists. With them, the reader is compelled to ask in these more cautious times, has the history of technology progressed as far as the technology it describes?

In reply, these two volumes invite comment at three levels. First, these chapters are, in technical terms, proverbially encyclopaedic in breadth and detail. Like their predecessors, these volumes describe a spectrum of activity, from fuels to food, metals to textiles, chemicals to buildings and transportation. Some chapters bring the story 'up to date'; others (space, aircraft, medical and ocean technology, and computers) describe recent additions to the "relief of man's very brief, is in the book edited by Edward Lawless, published by Rutgers University Press in 1977 (reviewed in Nature, 274, 295-296; 1978) under the unpromising title Technology and Social Shock.

So there is now the nucleus of a library which will promote the evolution of science-and-society into a respectable discipline. Dorothy Nelkin's latest contribution to this is very welcome.

Lord Ashby is Chancellor of Queen's University, Belfast, and Fellow of Clare College, Cambridge, UK.

estate". Although experts may differ (a possibility frequently raised, if indifferently addressed), one can scarcely debate the pronouncements of Lord Montagu of Beaulieu on motor cars, or of Colin Buchanan on town planning. Several other chapters - including Frank Greenaway's on instruments and Brian Bowers' on electricity - offer fresh insights as well as information. But these technical chapters together seem less than the sum of their parts. There is, despite the editor's catholicity, a deceptive provincialism of outlook which emerges in many of them. A mixture of "practical men" and university men (in about equal parts) is not necessarily an unsatisfactory formula for a fine product; but the fact that the contributors are overwhelmingly British, and, with perhaps ten exceptions, are not professional economic or social historians, points clearly to one difficulty. Another lies in the subject-matter itself.

One cannot criticise the authors for failing to make obligatory reference to microelectronics or biotechnology (although, indeed, there are none). But it will not escape notice that many of the 58 contributions (notably excepting the editor's own) follow historiographical conventions remarkably similar to those of educated amateurs a generation ago. Most technical chapters are history preserved in aspic, sadly neglecting systematic comparative analytical discussion. Excellent descriptive accounts of leading technical developments in different fields may nonetheless strike many a current reader, of say, "Technology and Culture", as dry, stylised and lacking in economic and social insight. On the one hand, few of the technical chapters even attempt to demonstrate the connection between entrepreneurial and management styles in research and development, and the problems of marketing and diffusion in different countries under different economic systems. On the other hand, few contributors pause to ask, how can we use this knowledge to understand the developments of the next twenty years?

Second, as the editor explains, technology advances across a broad front, or not at all. Yet the editorial arrangement of technical contributions, inevitably dividing knowledge into arbitrary categories, militates against the authors asking larger questions about the nature of the technologies concerned. Today, whatever may be one's opinion, for example, of 'appropriate technology', the reader will want to know in what ways technological development (whether in fuel, transport, housing, and so on), has been shown capable of responding to altered economic and social realities. It could be argued, in defence, that in the 1950s, most scholars and the English reading public were as uninterested in the relationships of production as they were unaware of the implicit risks of technological development.But whatever one's approach to economic history, no account of technological development which omits to describe the organisation and operation of the modes of production characteristic of industrial capitalism can today be considered complete.

If this criticism is sound, it is even more to be regretted, as the editor is clearly sensitive to the issues involved. Indeed, for this reason, $\mathrm{Mr}$ Williams has gone outside the ranks of the technological cognoscenti, and has invited several chapters of contextual discussion - including an historical overview from T.K. Derry, and chapters on innovation by David Sawers; on the economics of technology by Frank Bradbury; on management by Glenn Porter; on trades unions by Harold Pollins; on education by David Layton; on government by Alexander King; and on the chemical industry by Lutz Haber. These contributions are of varying quality (Haber's and Layton's in particular deserve a wider readership), but whatever their individual merits, they do not together weave a comprehensive fabric. Written, one supposes, in isolation from each other, they largely fail to reveal the depths of controversy reigning within these areas of discourse. The explanations offered are, in many ways, too consensual, too safe, and altogether too undemanding. When they jar, then, like a clock striking thirteen, they cast doubt on all else. For example, David Sawers concludes provokingly that "the nature of ... technology appears to influence the nature of the industrial structure more than the structure influences the technology". Surely, the two volumes of evidence which follow could, if skilfully used, demonstrate, disprove, or at least illuminate this assertion. At the very least, the economic and social analysis of new technologies cannot be merely relegated to separate chapters. At a more philosophical level, far more could be said about the relationship between technology and cultural expectations. For example, it could be argued (with important qualifications) that a presumed alliance between liberal values and technological growth was widely considered axiomatic in the 19th century; but Derry's passing reference to this fails to demonstrate why this should have been so, or what relevance 